\title{
Legal Certainty Deed of Land Sale and Purchase and Building Conducted by Husband and Wife After Divorce Based on Government Regulation No. 24 Of 1997 On Registration Of Land in The City of Cirebon
}

\begin{abstract}
Abdul Syukur ${ }^{1}$ and Lathifah Hanim ${ }^{2}$
Abstract. The purpose of this study was to: 1) To Know and analyze how the Rule of Law Deed of Sale and Purchase of Land and Building conducted by husband and wife after divorce based on Government Regulation No. 24 of 1997 on Land Registration in the city of Cirebon. 2) To Know and analyze the weaknesses of the Sale and Purchase Agreements Law of Land and Buildings performed by husband and wife after divorce based on Government Regulation No. 24 of 1997 on Land Registration in the city of Cirebon. 3) To Know and analyze how solutions address the legal shortcomings Deed of Sale and Purchase of Land and Building conducted by husband and wife after divorce based on Government Regulation No. 24 of 1997 on Land Registration that occurred in the city of Cirebon. The data used in this study are primary data, secondary data and data that can support tertiary study, which was then analyzed by descriptive analytical method.

Based on the results of data analysis concluded that: 1) Rule of Law Deed of Sale and Purchase of Land and Building conducted by husband and wife after divorce based on Government Regulation No. 24 of 1997 on Land Registration in the city of Cirebon declared legally valid if in accordance with the terms of buying and selling land and buildings in accordance with article 37 paragraph 1 of Government Regulation No. 24 of 1997 and proving that the right to land and building will be transferred transitioning right evidenced by a deed made by and before PPAT that the deed of sale which will then be used as the basis of registration data change registration. 2) deficiencies, legal certainty deed of sale of land and building is done by husband and wife after divorce are on how the process of making the PPAT deed, the deed of sale signatories of both parties must be on the terms of buying and selling is done in the presence of public officials who authorized and paid in cash. 3) to overcome the solution weakness against legal certainty deed of sale of land and buildings before registering the land to the National Land Agency (BPN) requirements in the execution of the sale and purchase must be taken by both sides in this case the former husband and wife so that in the future no one one side of those demanding the validity of the deed of sale.

Keywords: Rule of Law; Sale and Purchase Agreements; Land Registry
\end{abstract}

\section{Introduction}

The land registry is a series of activities carried out by the Government continuously, continuous and regular, covering the collection, processing, accounting, and presentation as well as the maintenance of physical data and juridical, in the form of maps and lists, on plots and units home interchanges, including the granting of rights letter of receipt for parcels of land that the existing rights and ownership of the apartment units as well as certain rights which encumber. ${ }^{3}$

Land Registry conducted stetelah process of buying and selling land and buildings. Sale and purchase is a process that can be evidence of transfer of rights from the seller to the buyer. ${ }^{4}$ The basic principle is Bright and Cash, which is carried out in the presence of public

\footnotetext{
${ }^{1}$ Director of CV. AZZAM Jaya Sakti, email: uung1892@gmail.com

2 Faculty of Law, Universitas islam Sultan Agung.

${ }^{3}$ Article 1 ayat1 Government Regulation Number 24 of 1997 on Land Registration

${ }^{4}$ UUPA/BAL
} 
officials who authorized and paid in cash. This means that if the price paid is not paid then the sale process can not be done.

One goal is the transfer of ownership and purchase of an item. In the case of the sale and purchase of land and building in particular has its own legitimate requirement in Article pelaksnaanya where in article 37, paragraph 1 of Government Regulation No. 24 of 1997, affirmed that: Transitioning rights to land and property rights to the apartment units through purchase, exchange, donation, data entry company and a legal act of transfer of rights other than the transfer of rights via auction can only be registered if evidenced by a deed made by PPAT authorized under the provisions of the legislation in force. From the description of the article is clear that the transition process through the buying and selling of land is an intermediate form of legitimate and recognized by law.

Besides, after the transition process is complete land and buildings are required to also register on the National Land Agency (BPN). According to Article 3 of Government Regulation 1997 land registration aims:

- to provide legal certainty and legal protection to rights holders on a plot, apartment units and other rights registered in order to easily be able to prove himself as the holder of the relevant right.

- to provide information to the parties concerned, including the Government that can easily acquire the necessary data in performing legal acts concerning land parcels and units of flats that are already registered, for the orderly implementation of land administration.

Sale and purchase of land and buildings carried out by post-divorce husband and wife is a treasure to be sold together, this is because it affects to property in case of divorce between husband and wife, For the division of joint property by making a binding agreement fair and equal division, with a binding sale and purchase with a repurchase will certainly poses no problems for the parties.

According to Muhammad Syaifuddin, "Divorce is a term used to confirm the occurrence of an event such as breaking the law of marriage between husband and wife, with legal reasons, certain legal proceedings and certain legal consequences which must be confirmed before the court." 5

After the divorce will have a great impact not only for husband and wife who divorced termination of rights and obligations between husband and wife is. One was against joint property, and if a marriage ends, joint property shall be divided equally between the husband and wife so long as the parties do not agree otherwise. The division of community property either in the form of moving objects or immovable property can be done either through mediation, consultation amicably or through a court decision.

If the spouses intends to sell, lease or mortgage joint property must be with the consent of both parties, if the divorce happens as a result of a court decision. The process of transfer of rights of land and buildings when it is done must be in accordance with applicable regulations.

In the case of transfer of land rights of the husband and wife are divorced of the transfer of rights to land both of them must be in accordance with procedures and regulations that in the future there is no one party that demands due to the dissatisfaction of the parties, Based on the background mentioned above the authors are keen to carry out further research to be formulated in the form of research under the title: Legal Certainty Deed of Sale and Purchase of Land and Building conducted by husband and wife after divorce based on Government Regulation No. 24 of 1997 on registration of land in the city of Cirebon.

\footnotetext{
${ }^{5}$ Muhammad Syaifuddin, 2013, Hukum Perceraian, Sinar Graha, Jakarta, p.18
} 


\section{Research methods}

Based on the formulation of the problem and the purpose of the research, the method used is empirical juridical approach. Juridical means using legal norms that are explained by way of researching and discussion of legal regulations in force at present, while the meaning of the word empirical is doing research in the field with observation and interviews to compare regulations with the reality in the community. So it is a juridical empirical approach is an approach taken to analyze about the extent to which a rule / law or the law being applied effectively, particularly regarding how legal certainty deed of sale of land and buildings carried out by the husband and wife after divorce based pemetintah regulation No. 24 of 1997 on the Registration of land in the city of Cirebon.

\section{Results And Discussion}

Marriage is a sacred promise bond between a man and woman to live together. In matrimony course everybody wants a prosperous family. Prosperous family is a family that made by a valid marriage, is able to make ends meet spiritual and material worth, fear of God almighty one, has relation harmonious and balanced between members, and among families with the community and the environment, with the number of children ideal for creating prosperity and unseen. ${ }^{6}$

In Article 1 of Act No. 1 of 1974 on marriage, provides a definition that marriage is a bond of spiritual and physical between a man and a woman as husband and wife relationships aim to establish a family (household) who are happy and everlasting based on God. From these definitions, marriage has five elements, namely:

- Bonding the inner and outer

What is meant is that the inner and outer bond in marriage it is not just enough to bond birth or mind alone, but both must be closely integrated. A bond of birth is a bond that can be seen and revealed the existence of formal relationships, relationships that are not visible. Not real, that can only be perceived by the parties concerned. This bond is a bond of birth. This bond to which can be used as a foundation in forming a happy family. So the marriage was not entered into the element of birth alone, but also involves an element of deep and sublime.

- Between a man and a woman

Marital bond can only occur between a man and a woman. Thus, the bond of marriage other than between men and women is not possible, for example, between a man and a man, a woman with a woman or a transvestite with a transvestite. In this element of marriage between a man and a woman contains the principle of monogamy.

- As husband and wife

The bond between a man and woman as husband and wife can be seen when they are based on the bond of a valid marriage is when eligible predetermined legislation.

- Marriage interest

The purpose of marriage is to form a happy family and eternal. What is meant here is a whole family consisting of father, mother and child which is the basic principle arrangement of Indonesian society in order to realize the welfare of society.

- Based on God

According to Article 1 of Act No. 1 of 1974 on Marriage formulate, that bond of husband and wife is based on the divinity of the Almighty, marriage is a sacred bond. Engagement can not let go of the religious affiliation of husband and wife.

\footnotetext{
6 Muhammad Djumhana, 1994, Hukum Ekonomi Sosial Indonesia, Bandung: PT Citra Aditya Bakti,p.111.
} 
In Islamic law, the definition (ta'rif) marriages under Article 1 Compilation of Islamic Law is marriage, ie: aqad which very strong or mitsaaqaan ghazliizhan to obey the commands of Allah and implement the worship.?

In marriage contained in the BW (Civil Code) HOCI (Huwelijken Ordinance Christen Inlanders/Christian Marriage Ordinance Indonesia) containing only civil marriage as a relationship, the conception of marriage contained in Act No. 1 of 1974 about basing marriage on the basis of spiritual marriage. Then this may be based on the basis of Pancasila state in which there is an element of Belief in One God.

According to the Civil Code, a valid marriage is a marriage made in advance civil registration office clerk. Marriages were performed according to the procedure alone is not a legitimate religion. ${ }^{8}$ Such provisions differ by Act No. 1 of 1974 on Marriage, as ius constitutum have a legal norms regarding legitimate marriage imperatively in Article 2, which reads:

- Marriage is legal if it is done according to the law of each religion and belief.

- Each marriage recorded under the applicable law.

Marriage law creates a husband and wife relationship between a man and a woman, which give rise to rights and obligations of each or together in the family. In other words, marriage raises the roles and responsibilities of the husband and wife in the family, either individually.

The provisions in Article 31 of Act No. 1 of 1974 on the marriage determines that the rights and position of wives is balance bunch of rights and status of the husband in domestic life and social life together in society, and each party is entitled to me; do legal acts and husband is head of the family and the wife as homemaker.

In upholding the household happy, prosperous and eternal become the basic principle structure of society, the husband and wife assume liability sublime. In reaching the obligation of husband and wife love each other, respect, loyal, and provide assistance inner and outer one to the other. These obligations listed in Articles 30 and 33 of marriage law.

As head of the family, the husband does not have rights in excess of the wife or wives wife. The provisions in Article 34 paragraph 1 of the Marriage Act specifies that the husband is obligated to protect his wife and provide everything need of home according to his ability. Of these provisions is clear that the husband's obligation to endure the cost of a householder's life purposes in accordance with his income.

In the provision of Article 34 paragraph 2 of the Marriage Act specifies that, "The wife shall manage the affairs of the household as well as possible". Thus as a homemaker, a wife berkwajiban to organize and regulate domestic use everyday as well as possible.

After a man and a woman engage in the institution of marriage, then start the rights established their obligation to be one. In case this does not mean that the rights and obligations of each party will be merged, but the rights and obligations they remain intact even though they have been united in life. For that they have to understand and respect one another. Not feeling one as ruler and the other being a slave, do not feel one of their most meritorious and others boarded.

An understanding of these rights and obligations to be very important and very fundamental, if we are going to examine more deeply about the consequences of marital life, as in marriage, will give birth to rights and obligations among other things about the child and the rights of property obligations. Because in our marriage will recognize

\footnotetext{
7 Asmin,1986, Status Perkawinan Antar Agama Ditinjau dari Undang-Undang Nomor 1 Tahun 1974, Jakarta: Dian Rakyat,p.28

8 Ali Afandi, Hukum Keluarga Menurut Kitab Undang-Undang Hukum Perdata(Burgelijk Wetboek), Yogyakarta: Yayasan Gajah Mada,sa.,p.5. in Tan Kamello and syarifah Lisa Andriati,op.Cit.,p. 87.
} 
community property. Where in the Act of marriage, treasure together in marriage is marital property acquired peace in matrimony.

Domestic life is loving, affectionate and fun is the dream of every couple. But along the way is not as easy as envisioned, like the ships that sailed the seas broad inseparable from the threat of storms and waves. The oceans have ups and downs the domestic life will experience, etc. Sometimes marital relationship sweet and affectionate, but at certain times of heat and worrisome bias. Marriage has been established by God as true and legitimate way to get the kids and for the prosperity of the earth. God makes the desire to get a mate and children as an instinct for humans and animals. Life on earth continues through the children and the children are the result of the marriage.

However, marriage in Islam can not be considered simply as a means to unify physical men and women to have children, as well as sodium absorption ratio marriage was instituted just for satisfy natural desires or passions flare up. There is no doubt that marriage is based on the principles of love, respect and mutual concern far more sublime than the temporal relationships with various partner. ${ }^{9}$

Marriage in Islam is a strong bond that weaves the couple in order to achieve domestic tangle of love and affection. On the other hand it is a religious marriage that is noble and great. Anyone carrying out a wedding on top of piety to God, he will reach the goal of being more perfect wedding and religion. Islam is keeping this sacred bond so as not to jiggle let alone released.

But two people who each have a character, character, distinct personality and plus external influences, sometimes there is a gap between both. Among the biggest factors triggering the problem of household is less understanding their respective duties between husband and wife. Although basically do marriage is aiming for ever, but sometimes there are certain reasons that led to marriage can not be continued so should be decided in the middle of the road or for attrition by itself, or in other words the divorce between husband and wife.

After the divorce will be a lot of things that arise between husband and wife, one of which is ownership of property that had been owned during the marriage. Automatically treasure there should be a division of the two sides. If the joint property in the form of ownership of land and buildings will be made transfer of rights to another party it must involve both parties in this case ex-husband and ex-wife.

The process of transfer of rights of land and building is done through the purchase would involve ex-husband and wife, as it requires the consent of both parties. All processes must be taken in the case of transfer of land rights and the building. Terms and condition should be taken to ensure legal certainty deed of sale of land and buildings dilakukkan by husband and wife after divorce have a legitimate legal force to be made binding sale and purchase deed before a notary in accordance with the clauses of the agreement. All the weaknesses in the certainty of the deed of sale of land and building post-divorce couple can be minimized as long as all processes are met prior to submitting the Land Registry in accordance with Government Regulation No.24 of 1997.

\section{Closing}

\subsection{Conclusion}

- Legal Certainty Deed of Sale and purchase of land and building is done by husband and wife after divorce have binding legal force and legitimate rights if the transition process

\footnotetext{
9'Jones Jamilah, 2001, Monogami dan Poligami dalam Islam, Jakarta : PT.Raja Grafindo Persada,
} p.12 
was completed according to the procedures contained in the Government Regulation No. 24 of 1997 concerning land registration.

- The weakness of the legal certainty of the deed of sale of land and buildings that do husband and wife after divorce can be minimalize with the provisions of the applicable land registration process in accordance with Government Regulation No. 24 of 1997 on Land Registration.

- The solution of the weaknesses in the legal certainty of the deed of sale of land and buildings were carried out after the divorce that the husband and wife at the time of buying and selling process both sides presented so that in the future no one party from those demanding the validity of the deed of sale.

\subsection{Suggestion}

Legal certainty deed of sale of land and buildings carried out by the husband and wife after divorce based on government regulation of 1997 on land registration that occurred in the city of Cirebon transitioning rights expected made binding sale and purchase deed before a notary in accordance with the agreed clauses and all of them must be approved by both parties in order to not cause problems in the future.

\section{Bibliography}

[1] Ali Afandi, Hukum Keluarga Menurut Kitab Undang-Undang Hukum Perdata (BurgelijkWetboek),Yogyakarta:Yayasan Gajah Mada

[2] Asmin,1986, Status Perkawinan Antar Agama Ditinjau dari Undang-Undang Nomor Tahun 1974, Jakarta: Dian Rakyat.

[3] Budiono Herlien, 2013, Kumpulan Tulisan Hukum Perdata di Bidang Kenotariatan. Bandung : Citra Aditya Bakti

[4] Lubis Abd Rahim, Lubis Yasmin, 2012, Hukum Pendaftaran Tanah. Bandung : CV.Mandar Maju

[5] Muhammad Djumhana, 1994, Hukum Ekonomi Sosial Indonesia, Bandung: PT Citra Aditya Bakti.

[6] Muhammad Syaifuddin, 2013, Hukum Perceraian. Sinar Graha.Jakarta

[7] Sembiring Rosindar, 2017, Hukum Keluarga, Depok : PT. Raja Grafindo Persada

[8] Samsaimun, 2016, Peraturan Jabatan PPAT. Bandung: Pustaka Reka Cipta

[9] Code of Civil law

[10] Act No. 1 of 1974 on marriage

[11] Agricultural Basic Law

[12] Government Regulation No. 24 of 1997 concerning land registration 